Agro-Science Journal of Tropical Agriculture, Food, Environment and Extension Volume 19 Number 2 (Apr. 2020) pp. 31 - 35

ISSN 1119-7455

\title{
EFFECT OF NATURAL PRESERVATIVES ON THE ORGANOLEPTIC CHARACTERISTICS AND STORAGE STABILITY OF SMOKED Heterotis niloticus
}

\author{
${ }^{* 1}$ Amuneke K.E., ${ }^{2}$ Oguntade O.R., ${ }^{1}$ Ikeogu F.C. and ${ }^{1}$ Nomeh U.A. \\ ${ }^{1}$ Department of Fisheries \& Aquaculture Management, Nnamdi Azikiwe University Awka, Nigeria \\ ${ }^{2}$ Department of Biotechnology, Nigerian Institute for Oceanography, Marine Research Lagos, Nigeria \\ Corresponding author’s email: ke.amuneke@unizik.edu.ng
}

\begin{abstract}
Improvement of consumer's palatability of Heterotis niloticus was investigated by value addition with natural spices and salt to improve its palatability and shelf-life. The major problem of $\mathrm{H}$. niloticus is its poor taste, hence low demand and poor consumer's acceptability which affects the market value. The objective of this study was to improve the palatability and shelf-life of H. niloticus using selected natural spices. Heterotis niloticus, procured and treated with natural spices and salt were allowed to drain for one hour, subjected to charcoal fired smoking kiln for 12 hours, cooled and stored for 8 weeks at ambient temperature before microbial analysis. The result showed that treatment 1 had the best quality (37.7\%), followed by control sample (34.7\%), and treatment 2 (28.9\%), while the least was treatment 3 (21.6\%). Microbial analysis shows that no Salmonella, Coliforms and E. coli were detected from the samples after smoking. Staphylococcus aureus count ranged from $2 \times 10^{2}$ to $9 \times 10^{2}$ but it was not detected in treatment 1 . Improvement of the consumers' palatability of $\mathrm{H}$. niloticus and improved storage stability by spicing methods improved the poor taste of $\mathrm{H}$. niloticus which has been discriminated despites excellent muscle quality.
\end{abstract}

Key words: Heterotis niloticus, organoleptic, spicing, microbial analysis

\section{INTRODUCTION}

Fish is an important source of food, income, employment and recreation for people around the world and it is a very important source of animal protein for both man and livestock in developed and developing countries (Emmanuel et al., 2014; Amponsah et al., 2016; FAO, 2014). Nutritionally, fish is an important and rich source of affordable protein characterized by a desirable composition of amino acids (Pasqualino et al., 2016), vitamins A, $\mathrm{B}$ and $\mathrm{D}$ as well as minerals like calcium, iodine, selenium, zinc and iron (FAO, 2012). Besides its acceptance as a balanced source of animal protein and vitamins, fish also provides polyunsaturated fatty acids (PUFAs) and minerals necessary for optimal health (Allision, 2011).

However, nutritional benefits from fish and fish products are limited by its rapidly perishable nature and vulnerability to spoilage (Modibbo et al., 2014; FAO, 2016). Spoilage in fish occurs because it is susceptible to microbial and enzymatic deterioration which results in quality reduction, especially in the absence of proper processing and storage techniques. Generally, during post-harvest period large amounts of fish spoil and waste due. This is not only due to lack of proper measure for processing and preservation, but also to the fact that normally not all the fishes caught are consumed and they are not transported to other places they are needed due to insufficient handling and transportation system.
In Nigeria and other countries in sub-Saharan Africa where fish offers about $40 \%$ protein intake of the people, Heterotis niloticus is one of the species that has great potentials for commercial aquaculture (Olatunde, 1989). The species has excellent flesh quality and good source of amino acids (Monentcham et al., 2009), but is associated with low acceptability by consumers due to its poor taste. There has been great setback to consumers' demand of this fish which affects the market value. This results to $H$. niloticus being used mostly in many places for feed preparation instead of human consumption. Because of this problem it is barely known, cultured and consumed by fish consumers thereby reducing its market value. There is need to address the problems of poor taste and wastage by adding value to the fish to improve its consumer taste which would increase its demand, thereby attract better market value for the fish.

Also, in order to meet the complex and long chain of distribution as well as fish food security, it is important to ensure proper fish preservation using natural preservatives that can improve organoleptic properties of fish and also extend its shelf-life. Therefore, the use of natural preservatives like ginger, nutmeg and pepper in combination with sodium chloride which can inhibit microbial growth in smoked fish during storage becomes important (Deo, 1998). There is scanty of 
information regarding the impact of natural preservatives and different storage times at room temperature on the microbial quality and palatability of smoked $H$. niloticus. This study was on the effect of selected natural preservatives on the changes in microbial population and quality of smoked $H$. niloticus during 8-week ambient storage. The general objective of this study was to improve the palatability of $H$. niloticus to fish consumers using selected natural spices and improve its shelf-life also.

\section{MATERIALS AND METHODS Sample Collection}

Four table-sized fish samples of $H$. niloticus with a total weight of $12.7 \mathrm{~kg}$ were purchased from the artisanal fishermen at Otuocha market in AnambraEast Local Government Area of Anambra State. It was conveyed down to Nnamdi Azikiwe University Research Farm in an ice-filled plastic bowl covered with a sack bag to prevent deterioration.

\section{Sources of Spices and Other Materials}

Some spices including Ginger (Zigiber officinala), Nutmeg (Myristica fragrans), Cameroon pepper (Capsicum chinense) and common salt (Sodium chloride) were obtained from a local market (Eke Awka) in Awka, Anambra State. Other materials like charcoal were equally sourced locally from Eke Awka while smoking kiln was used in the smoke drying of the fish samples.

\section{Sample Preparation}

The collected fish samples were scaled, gutted and washed severally and then chunked into 48 pieces as each spice were replicated into three places. The three spices used; were $g$ grinded into powder using grinding machine (Manual Multi-function Grinder Machine, model JR 10). The spices were placed in $100 \mathrm{~g}$ cup and $50 \mathrm{~g}$ each was weighed using a sensitive scale (Atom A 122 Electronic kitchen digital weighing scale, model SF: 400A). Each spice was added $10 \mathrm{~g}$ of salt and mixed with half a liter of water. The fish samples were then soaked in the prepared spice extract for $1 \mathrm{~h}$, placed on smoking trays, tagged and allowed to drain water and placed into the smoking kiln. The fourth sample soaked in $10 \mathrm{~g}$ of salt served as the control.

\section{Fish Processing}

The treated samples were replicated three times as well as the control. The drying of the fish samples was done using a charcoal fired smoking kiln. They were subjected to heat and allowed to dry for $12 \mathrm{~h}$ with turning at intervals to achieve a uniformly dried product. The fish samples were cooled, removed from smoking kiln and tagged as: salt only: Control, Ginger + salt: Treatment 1, Nutmeg + salt: Treatment 2, Cameroon pepper + salt: Treatment 3 .

\section{Organoleptic Evaluation}

Subjective analysis was used for organoleptic characteristics analysis, in which staff and students of Nnamdi Azikiwe University, Awka were used to carry out the tests. Five members of the panel were selected for each parameter like flavour, texture, appearance and taste trained on the rudimentary aspects of organoleptic characteristics and how to apportion mark to each parameter. The fish samples were given out with questionnaires for the panel members to feel and taste the fish products and score based on how it appealed to the taste, texture, appearance and flavour.

\section{Pre-Storage Microbial Analysis of the Samples Initial microbial sample isolate}

One gram (1 g) representative sample was obtained aseptically from the loin muscle of the smoked $H$. niloticus samples. The samples were grounded and serial dilutions $\left(10^{-1}-10^{-4}\right)$ of the homogenized samples were made using sterile distilled water.

\section{Total plate count (TPC)}

This was done using the pour plate method of Harrigan and McCance (1976). One milliliter of the serially diluted samples was taken in duplicates and plate count agar was poured at $40{ }^{\circ} \mathrm{C}$ on the plates. The samples and the medium were properly mixed, allowed to set and incubated at $35{ }^{\circ} \mathrm{C}$ for $24 \mathrm{~h}$. The number of colonies on the plates was counted.

\section{Staphylococcus sp. count}

Manitol salt agar was used to enumerate the number of Staphylococcus colonies. The plates were incubated at $35{ }^{\circ} \mathrm{C}$ for $24 \mathrm{~h}$ and bright yellow colonies were counted. The bright yellow colonies were sub-cultured for additional $24 \mathrm{~h}$ and coagulase test was carried out to confirm the presence of Staphylococcus aureus.

\section{Coagulase test}

A small amount of the colony was introduced into blood plasma, formation of clots or coagulation of plasma showed the presence of $S$. aureus.

\section{Salmonella count}

Samples for detection of salmonella were plated out on Salmonella-Shigella Agar. The plates were incubated at $35{ }^{\circ} \mathrm{C}$ for $24 \mathrm{~h}$. Black colonies showed the presence of Salmonella sp.

\section{Escherichia coli count}

This was done using Eosine Methylene Blue Agar at $35{ }^{\circ} \mathrm{C}$ for $24 \mathrm{~h}$. Colonies with green metallic sheen were counted as $E$. coli

\section{Coliform count}

This was also done using Eosine Methylene Blue Agar at $35{ }^{\circ} \mathrm{C}$ for $24-48 \mathrm{~h}$. The samples were first inoculated into lactose broth for 48 hours. The production of gas in the Durham's tubes showed the presence of coliforms. The samples showing gas production were plated out and counted. 
Post Ambient Storage Microbial Analysis

After 8 weeks in storage at ambient temperature, the different treated samples of the smoked $H$. niloticus were subjected to microbial load analysis.

\section{Sample Preparation}

One gram $(1 \mathrm{~g})$ of each of the treated fish samples and their replicates were weighed out aseptically and introduced into $10 \mathrm{ml}$ of sterile peptone water in a test tube, it was properly shaken to homogenize the sample. A 10 -fold serial dilution of each of the sample was carried out using peptone water as the diluents. A known volume $(0.1 \mathrm{ml})$ of appropriate dilutions $\left(10^{-2}\right.$ and $\left.10^{-3}\right)$ of the sample were pour plated in sterile plates of Nutrient agar (NA) plates and MacConkey agar plates for the cultivation of bacteria. All cultured plates were incubated at $37^{\circ} \mathrm{C}$ aerobically for 24-48 h. Developed colonies were counted to obtain total viable count and coliform counts respectively. Discrete colonies were obtained by sub culturing into Nutrient agar plates and were subsequently identified using standard methods.

Characterization and Identification of Bacteria Identification of the bacterial isolates was done by the observation of colonial characteristics, Gram reaction and biochemical tests (Cheesbrough, 1984). The characterization of the isolates was performed, by employing Gram staining reaction, Catalase test, Citrate test, Sugar fermentation test, Oxidase test, Coagulase test, Motility test, Indole test, Methyl Red and Voges proskauer test as described by Bergey and Holt (1994).

\section{RESULTS}

\section{Organoleptic Properties of Heterotis niloticus}

The organoleptic properties of treated and smoked Heterotis niloticus are shown in Table 1. The overall performance shows that treatment 1 had the highest value $(38.5 \%)$ in terms of flavour, while the least $(23.1 \%)$ acceptable flavour was recorded by treatment 3 , treatment 2 , and the control had $30.8 \%$ acceptability in flavour. The result shows that the flavour of treatment 1 differed from that of treatment 3 and no difference was observed in flavour of treatment 2 and control. The control sample had the best appearance $(38.5 \%)$ while treatment 3 had least (15.4\%) accepted appearance. The result shows slight difference in the appearance of treatment $1(36.9 \%)$ and control $(38.5 \%)$ samples, but differs greatly from treatment $2(26.2 \%)$ and treatment $3(15.4 \%)$ samples. The texture of the control sample $(38.5 \%)$ and treatment 1 (36.9\%) were better when compared with that of treatment 3 (24.6\%). The taste parameter showed that treatment 1 had $38.5 \%$ acceptability followed by control and treatment $2(30.8 \%)$, while the least was $23.1 \%$ acceptability in treatment 3 . However, there were no differences recorded in treatment 2 and control samples, while major difference exist between treatment 3 and other treatments.

\section{Microbiological Analysis}

The result of the microbial analysis of $H$. niloticus treated with some selected natural preservative and smoke-dried before storage for eight weeks at ambient temperature showed reduced total plate count of day zero (0) for the samples. The total plate count for freshly smoked samples ranged from $34 \times 10^{2}$ to $35 \times 10^{3} \mathrm{CFU} / \mathrm{g}$ for day zero samples (Table 2). Salmonella, the pathogenic microorganism examined, for freshly smoked fish prior to storage was not detected in any of the samples. No coliforms and E. coli were found in any of the treated samples after smoking. The pathogenic organisms, $S$. aureus counts ranged from $2 \times 10^{2}$ to $9 \times 10^{2} \mathrm{CFU} / \mathrm{g}$. Nonetheless, the microbial populations for the entire treated smoked fish sample observed in this study before storage were within the recommended limits for good quality fish product according to ICMSF (1986).

Table 3 shows the mean value of the total viable count (TVC) of bacterial load in H. niloticus after storage in ambient room temperature for a period of 8 weeks with a total viable count ranged from $3.4 \times 10^{5} \mathrm{CFU} / \mathrm{ml}$ in treatment 1 to $7.8 \times 10^{5}$ $\mathrm{CFU} / \mathrm{ml}$ in control sample. These are above the recommended WHO Standard $\left(1.0 \times 10^{3} \mathrm{Cfu} / \mathrm{ml}\right)$.

Table 2: Microbial population in freshly smoked preservative treated $H$. niloticus

\begin{tabular}{lcccc}
\hline $\begin{array}{l}\text { Microbial } \\
\text { Population }\end{array}$ & \multicolumn{4}{c}{ Mean value of microorganism CFU/g } \\
& $\begin{array}{c}\text { Treat- } \\
\text { ment } 1\end{array}$ & $\begin{array}{c}\text { Treat- } \\
\text { ment 2 }\end{array}$ & $\begin{array}{c}\text { Treat- } \\
\text { ment 3 }\end{array}$ & Control \\
\hline TPC & $35 \times 10^{3}$ & $12 \times 10^{3}$ & $34 \times 10^{2}$ & $25 \times 10^{3}$ \\
Salmonella & ND & ND & ND & ND \\
Staphylococcus & ND & $3 \times 10^{2}$ & $9 \times 10^{2}$ & $2 \times 10^{2}$ \\
Coliforms & ND & ND & ND & ND \\
E.coli & ND & ND & ND & ND \\
\hline
\end{tabular}

TPC - total plate count, CFU - colony forming unit,

ND - not detected, Control - salt treated,

Treatment 1 - ginger + salt, Treatment 2 - nutmeg + salt,

Treatment 3 - pepper + salt

Table 1: Sensory scores of smoked $H$. niloticus with natural preservatives

\begin{tabular}{|c|c|c|c|c|c|}
\hline \multirow[b]{2}{*}{ Preservative } & \multirow[b]{2}{*}{ Overall acceptability } & \multicolumn{4}{|c|}{ Percentage (\%) perception of respondent } \\
\hline & & Appearance & Texture & Taste & Flavour \\
\hline Control & 34.7 & 38.5 & 38.5 & 30.8 & 30.8 \\
\hline Treatment 1 & 37.7 & 36.9 & 36.9 & 38.5 & 38.5 \\
\hline Treatment 2 & 28.9 & 26.2 & 27.7 & 30.8 & 30.8 \\
\hline Treatment 3 & 21.6 & 15.4 & 24.6 & 23.1 & 23.1 \\
\hline
\end{tabular}

Control: Salt treated, Treatment 1: Ginger + salt, Treatment 2: Nutmeg + salt, Treatment 3:Pepper + salt. 
Table 3: Total viable count (TVC $(\mathrm{CFU} / \mathrm{ml}))$ of treated ambient stored $H$. niloticus

\begin{tabular}{lcc}
\hline Treatments & $10^{-2}$ dilution & $10^{-3}$ dilution \\
\hline Control & $1.42 \times 10^{5}$ & $7.8 \times 10^{5}$ \\
Treatment 1 & $7.2 \times 10^{4}$ & $3.4 \times 10^{5}$ \\
Treatment 2 & $1.28 \times 10^{5}$ & $7.5 \times 10^{5}$ \\
Treatment 3 & $9.6 \times 10^{4}$ & $4.2 \times 10^{5}$ \\
\hline
\end{tabular}

CFU - colony forming unit (WHO's standard $1.0 \times 10^{3} \mathrm{CFU} / \mathrm{ml}$ ), Control - salt treated, Treatment 1 - ginger + salt,

Treatment 2 - nutmeg + salt, Treatment 3 - pepper + salt

\section{DISCUSSION}

The result of organoleptic properties of spice treated smoked $H$. niloticus in this study shows improved end product and a prolonged shelf- life in $H$. niloticus, this may not be unconnected to the fact that the spice treatment and the smoking process seem sufficient to have destroyed microbes. The absence of visible mould mass under ambient condition observed in this study indicates the effectiveness of spices as anti-fungal agents and resulted in the extended shelf-life of spice treated samples; this agrees with the report of Kumolu-Johnson et al. (2015) that ginger extract was effective in reducing microbial load in the stored fish sample. Also, the low level of contamination in freshly processed products and the lack of post-processing contamination as shown in Table 2 indicated general good sanitary conditions at point of collection and processing. A combination of preservative treatment and smoking result might have equally contributed to this low record in variations of microbial levels.

Furthermore, the microbial results observed in this study are in agreement with the studies of Kumolu-Johnson and Ndimele (2011) in which it was observed that there was a reduction in microbial proliferation and lipid oxidation in the samples treated with ginger paste, Ikeme and Bhandary (2001) and Sallam et al. (2004) in which ginger and garlic paste were effective in retarding the development of oxidative rancidity in mackerel, (Scomber scombrus) and chicken sausage, respectively. These results also indicate that ginger which is natural spice clearly has anti-fungal properties that can compare with synthetic antimicrobial agents like potassium sorbate, citric acid and sodium metabisulphite (Omojowo et al., 2008). Kiin-Kabari et al. (2011) showed that Piper guinensis, Myristica monodora and Xylophia aethiopicum had chemical preservative and antioxidant properties which have effective preservation potential for smoked-dried fish during storage by retarding growth of microorganism and thus extend the shelf- life of fish. These antioxidants could be part of the reason for low microbial count after 8-week storage which makes the fish to remain within the acceptable limits recorded by International Commission on
Microbiology safety for food and for good fish product (ICMSF, 1986). Similarly, Oluborode et al. (2015) reported that the microbial analysis of fish samples (Clarias gariepinus) treated with 3 spices, ginger, garlic and combination shows that total viable counts (TVC) as well as bacterial species were not detected in the fish samples after smoking. This corroborates the result of this study. Furthermore, the result of this study confirmed report of Ihuahi et al. (2006) that Clarias gariepinus treated with mixture of pepper and garlic paste was more stable than untreated samples and have more acceptable organoleptic properties.

\section{CONCLUSION}

This study demonstrated the effectiveness of natural spice addition in improving consumer's palatability and controlling microbial population and pathogens in Heterotis niloticus by predicting the microbial safety and quality of smoked $H$. niloticus for 8 weeks ambient storage. The study shows that ginger plus salt is an efficient and effective spice for pre-treating fish (H. niloticus) before smoking for production of high quality, palatable and safe smoked-dried products. It was also evident from this study that the application of ginger plus salt and good/hygienic handling procedures adopted greatly improved consumer's palatability of the fish ( $H$. niloticus) and control microbial population. Hence ginger plus salt is recommended for pre-treatment of fish $(H$. niloticus) prior to processing especially when consumer's palatability and safety is desired.

\section{REFERENCES}

Allision E.H. (2011). Aquaculture, fisheries, poverty and food security. World fish Centre, 62-65

Amponsah S.K., Ofori-Danson P.K. and Nunoo F.K. (2016). Study of the population parameters of the big eye grunt, Brachydeuterus auritus (Valenciennes, 1831) in Ghanaian coastal waters and its implications for management. Int. J. Fisheries Aquatic Studies, 4, 413-419

Bergey D.H. and Holt J.G. (1994). Bergey's Manual of Determinative Bacteriology ( $9^{\text {th }}$ edn.) Williams and Wacket, Baltimore, Washington DC, 787 pp.

Cheesbrough M. (1984). Medical laboratory manual for tropical countries II: Microbiology, Cambridgeshire, Tropical Health Technology. ( $1^{\text {st }}$ ed.) Doddington, 219-235

Doe P.E. (1998). Fish Drying and Smoking: Production and Quality. ( $1^{\text {st }}$ edition) CRC Press, Florida, USA. pp. $45-53$

Emmanuel O., Chinyere A., Oluwatobi A. and Peter K. (2014). Review of aquaculture production and management in Nigeria. Am. J. Exp. Agric., 49, 11371151

FAO (2012). The state of world fisheries and aquaculture. Rome: FAO, 230

FAO (2014). The state of world fisheries and aquaculture. Rome, 223 
FAO (2016). The state of world fisheries and aquaculture: contributing to food security and nutrition for all. Rome, 200

Harrigan W.F. and McCance M.E. (1976). Laboratory Methods in Microbiology. Academic press, London. New York

ICMSF (1986). Microorganisms in Foods, Sampling for Microbiological Analysis: Principles and Specific Applications $\left(2^{\text {nd }}\right.$ ed. ) Blackwell Science, Oxford, 310

Ihuahi J.A., Omojowo F.S and Ugoala E. (2006). Effect of spice treatment on the quality of hot-smoked catfish (Clarias gariepinus). 363-369. In: Proceedings of $21^{\text {st }}$ Annual Conference Fisheries Society of Nigeria

Ikeme A.I. and Bhandary C.S (2001). Effects of spice treatment on the quality of hot-smoke mackerel (Scomber scombrus). FAO Fisheries Report No 467, FAO, Rome, Italy, 1-10

Kiin-Kabari D.B., Barimalaa I.S., Achinewhu S.C and Adeniji T.A. (2011). Effects of extracts from three indigenous spices on the chemical stability of smokedried catfish (Clarias lazera) during storage. Afr. J. Food, Agric., Nutr. Dev., 11, 1-9

Kumolu-Johnson C.A. and Ndimele, P.E. (2011). A review on post-harvest losses in artisanal fisheries of some African countries. J. Fisheries Aquatic Sci., 6, 365-378

Kumolu-Johnson C.A., Ndimele P.E., Ayorinde O.A . and Ojikutu T.I. (2015). Preliminary study on the antioxidative and anti-fungal effects of ginger oil on the shelf life of hot smoked fish. Am. J. Food Technol., 10, 74-78
Modibbo U.U., Osemeahon S.A., Shagal M.H. and Halilu M. (2014). Effect of moisture content on the drying rate using traditional open sun and shade drying of fish from Njuwa Lake in North-Eastern Nigeria. IOSR J. Applied Chem., 7, 41-54

Monentcham S., Whatelet B., Pouomogne V. and Kestemont P. (2009). Egg and whole-body amino acid profile of African bonytongue (Heterotis niloticus) with an estimation of their dietary indispensable amino acids requirements. Fish Physiol. Biochem., 36, 531-538

Olatunde A.A. (1989). Approaches to the study of fisheries biology in Nigerian inland waters. In: Ayeni M.E. and Olatunde A.A. (Eds.). Proceedings of National Conference of Two Decades of Research on Lake Kainji, 1538-1541

Oluborode G.B., Adelowo E.O. and Adenike U. (2015). The use of spice in prolonging the shelf-life of smoked Clarias gariepinus. In: Proceedings of $30^{\text {th }}$ Annual Conference Fisheries Society of Nigeria

Omojowo F.S., Omojasola P.F. and Ihuahi J.A. (2008). Microbial quality of citric acid as preservatives in smoked catfish (Clarias gariepinus). Biol. Environ. Sci. J. Tropics, 5, 130-134

Pasqualino M.M., Thilsted S.H., Phillips M.J. and Koroma A.S. (2016). Food and nutrition security in Sierra Leone with a focus on fish in Tonkolili District. Penang, Malaysia. World Fishery Program Report, 23, 30-34

Sallam K.I., Ishioroshi M.I and Samejima K. (2004). Antioxidant and anti-microbial effect of garlic on chicken sausage. Lebenson Wiss Technol., 37, 849-855 